\section{La Révolution française}

Cahiers de l'Institut d'histoire de la Révolution française

$8 \mid 2015$

Entre la Révolution et l'Empire : une nouvelle politique dans l'océan Indien

\title{
Myth and reality of Paolo Avitabile, the last European Free Lancer in India
}

\section{Antonio Lusardi}

\section{(2) OpenEdition}

\section{Journals}

Electronic version

URL: http://journals.openedition.org/lrf/1273

DOI: $10.4000 /$ Irf. 1273

ISSN: 2105-2557

\section{Publisher}

IHMC - Institut d'histoire moderne et contemporaine (UMR 8066)

Printed version

Date of publication: 23 June 2015

Electronic reference

Antonio Lusardi, « Myth and reality of Paolo Avitabile, the last European Free Lancer in India », La Révolution française [Online], 8 | 2015, Online since 24 June 2015, connection on 14 February 2020. URL : http://journals.openedition.org/Irf/1273; DOI : 10.4000/Irf.1273

This text was automatically generated on 14 February 2020

(c) La Révolution française 


\title{
Myth and reality of Paolo Avitabile, the last European Free Lancer in India
}

\author{
Antonio Lusardi
}

\section{The context. European Military Adventurers in India}

1 In $18^{\text {th }}$ and $19^{\text {th }}$ century Europe, and particularly in France, the word 'India' was associated with the idea of fabulous wealth and adventures. Part of this legend was created by the career of many men that during the hundred years between 1740's and 1840 's were in the service of many indigenous Indian states: the European military adventurers.

2 At beginning of this period, the battles of Sao Thomé (1746) and Plassey (1757) had shown to the Indian princes and nawabs the huge gap between their traditional armies and those of the European Commercial Companies. ${ }^{1}$. The rulers of the Indian states realized that the only possible way to beat their traditional foes and also resist the new European menace was to secure the secrets of the European warfare for their own armies $^{2}$. The most secure way to acquire the knowledge of European military tactics, technology and drilling was to hire a large number of European soldiers, officials and technicians, promising them huge wages. These men were in most cases deserters from the armies of the commercial companies but many of them arrived from Europe as freebooters only to seek fortune in the Indian indigenous states. The military adventurers formed new modern military units in the native states, based on the European warfare, centred on the firepower of infantry and artillery. In many cases they also established gun foundries and they were rewarded with large jagirs (fiscal and political rights on a territory) to supply and maintain their troops ${ }^{3}$.

3 The presence of the European military adventurers was large in many $18^{\text {th }}$ century Indian native states such as the Maratha princely states, the Mysore of Haidar Ali and Tipu Sultan or nizam's Hyderabad. These states were among those that pursued a large 
program of military modernization, offering employment to a growing number of adventurers during the last decades of the century ${ }^{4}$. The almost contemporary collapse of the French imperial ambitions on the Indian subcontinent following their defeat in the Seven Years War liberated a huge number of soldiers, officials and technicians willing to serve for the Indian princes. This presence of European mercenaries among the native armies was so extended that the years between 1763 and 1803 are named the 'Golden Age' of the adventurers 5 .

4 However, in the last decade of the $18^{\text {th }}$ century and in the first years of the $19^{\text {th }}$, the East India Company fought a number of wars that led the British to be the paramount power in India. The modernized armies of the Marathas and the Mysore were beaten due to their incapacity to modernize their political structure at the same pace as the military structure, leaving them substantially weak. Furthermore, the Indian armies were weakened by the desertion of many of the European adventurers who organized them, in many cases due to the corruption of the British political officers. The vast demilitarization of the subcontinent which followed the Second Maratha War and the increasing mistrust in the adventurers from both the British (the adventurers were mainly French or French-speaking) and the Indians stopped the presence of European freebooters in India for almost 20 years ${ }^{6}$.

In the 1820's the growing Sikh Empire of Maharaja Ranjit Singh needed to modernize its army, thus providing a renewed demand for European adventurers. Also the offer was rising, because the end of the Napoleonic Wars and the European Restoration had left many veteran officers without assignment. This 'second wave' of adventurers was far more limited than the 'golden age', but had many interesting personalities among them, such as Jean-Francois Allard, Jean Baptiste Ventura, Claude-Auguste Court, Alexander Gardiner and Paolo Avitabile?

6 The study of the lives and careers of the many adventurers, despite the many difficulties which it implies ${ }^{8}$, could be very revealing of the relations between the Europeans and the Indian natives. Furthermore it could shine a light on how the East India Company officers and the Victorian historians saw the presence of other Europeans in India during the making of their Empire. And this is precisely the case of Paolo Avitabile.

\section{From Peasant to General. A short account of Avitabile's life and career}

7 Paolo Crescienzo Martino Avitabile was born in Agerola, a small village between Napoli and Salerno, on 25th October 1791. The third of five sons of a peasant farmer, he enlisted in the militia of the newly-formed Napoleonic Kingdom of Naples in $1807^{9}$. From the militia Avitabile joined the artillery branch of the regular army in 1810. There he ascended through the ranks until he was appointed First Lieutenant of Artillery in early 1815, just before the Neapolitan War. He did not participate in the Northern campaign of King Murat, and after the latter's defeat at Tolentino he was incorporated in the army of the restored Borbonic Kingdom. Avitabile commanded his battery during the siege of Gaeta, the last stronghold of the Napoleonic loyalists, in July-August 1815. He distinguished himself during the operations, being also wounded in action, but due to the Convention of Casalanza ${ }^{10}$, after the peace he was stripped of his rank and forced onto half-pay in a reserve infantry regiment. With no further career prospects, 
Avitabile resigned from the army in 1816, and after a rather obscure period, he arrived in Constantinople in 1817, seeking military employment in Asia. There he was hired by an envoy of the Persian Shah Fath Ali and he served as a military instructor in Persia from 1818 to 1826. Under the sons of Fath Ali he exercised also some kind of civil authority in the Kurdistan area, using his levies to extract revenue from the local tribes ${ }^{11}$, He returned briefly to Naples in 1826 , but soon after went back to Asia seeking a new employment. On the suggestion of two of his former comrades in Persia (JeanFrancois Allard and Jean-Baptiste Ventura), now employed as military commanders under Ranjit Singh, the Maharaja of the Punjab, he decided to reach India. After a rather adventurous trip on the land route passing through Kabul and Peshawar ${ }^{12}$, Avitabile arrived at Lahore, the capital of the Punjab, in January 1827. After some months of negotiations he entered the service of Ranjit Singh as a military instructor and commander. For almost three years he retained only his military assignment and during this period he organized his infantry brigade on the European model ${ }^{13}$. It was in December 1829 that the turning point of Avitabile's career took place: he was appointed governor of the city and district of Wazirabad. From thence to his return to Europe in 1843 the main occupation of Avitabile was civil governorship, firstly of Wazirabad (until 1835) and secondly of Peshawar (from 1837) ${ }^{14}$. Despite his service as Kardar (Governor) was preeminent, Avitabile led his brigade in various occasions in those years, besides giving an invaluable support to the East India Company's invasion of Afghanistan ${ }^{15}$. The participation of Avitabile in the operations of the First Afghan War (as governor of Peshawar, a frontier city in a key position for the war) has proved to be the most important source of information we have about the carrier of the Neapolitan adventurer. The numerous British political and military officers who knew Avitabile in those years (1838-1842) left many accounts on the activities, personality and governorship of the Italian both in their official correspondence and memoirs ${ }^{16}$. In the following decades those memoirs and documents where used by numerous British historians to build a sort of 'black legend' around Avitabile's figure and its governorship at Peshawar. Despite this myth has been largely revised by many works in recent years, this image of Avitabile as a bloodthirsty butcher can be revealing of the British colonial historians and their view about governorship in the native states as well as in the EIC's territories.

8 Avitabile left his service and Punjab in 1843, after the bloody feuds for the Lahore throne that followed the death of Ranjit Singh. Back in Naples with a great fortune he lived quietly his last years in his native town and died in 1850. Nevertheless also in his last years in Italy he left behind him a conflicting memory and an obscure legend about his death ${ }^{17}$.

\section{The building of a black legend. Sources on Avitabile's governorship in Peshawar}

9 In order to understand the 'black legend' that was built in the late $19^{\text {th }}$ century around Avitabile's figure we need to briefly analyse his career in the service of Maharaja Ranjit Singh, particularly his governorship at Peshawar.

10 The original task of Avitabile in the Punjab's service was to organize and drill an infantry force on European military principles. This was his main activity for three years, and he continued to hold his assignment of brigade commander until his 
resignation in 1843. Unfortunately, despite this important charge and the long period he retained it, we don't know much about Avitabile's military activities. A few details about Avitabile's brigade are held in the Lahore archives $^{18}$ and some information about the Italian's participation in the main military campaigns can be found in various sources ${ }^{19}$.

11 The reason of Avitabile's fame (especially his negative one) lies in his two terms as governor, in particular in that at Peshawar. In December 1829 Avitabile was appointed Kardar (governor) of Wazirabad, which he governed for the following five years. It was not the first time he had exercised civil authority ${ }^{20}$, but this task was of much greater importance. At Wazirabad Avitabile created a unique style of governorship, merging European ideas in the management of revenue and trade ${ }^{21}$ with the local traditions in matters of justice and religion ${ }^{22}$. He also rebuilt the city with new wide streets and bazars $^{23}$. His governorship was not inspired by idealistic views, but by a huge pragmatism, which was essential to rule a country with so many ethnic groups, religions and customs effectively. Avitabile added to his pragmatism a great efficiency in every branch of activity. Under Avitabile's rule Wazirabad knew a period of peace and economic growth that was appreciated by many British and Indian observers ${ }^{24}$.

It was probably due to his successful management of Wazirabad that, after the 1835 campaign in the Peshawar valley, Avitabile was ordered by Ranjit Singh to remain in the pashtun city to supervise the revenue collection there, under the governor Hari Singh Nalwa ${ }^{25}$. Avitabile remained in charge of the revenue collection for about a year, before resigning and returning to Lahore after some dissent with the Sikh officials of the city ${ }^{26}$. However, after the death of Hari Singh Nalwa during the battle of Jamrud (April 1837), Avitabile was named Kardar of Peshawar ${ }^{27}$.

In regard of the huge difficulties in ruling this province, inhabited by Muslim Pashtuns with a strong hatred towards the recent Sikh dominators, the governor of Peshawar was provided with much greater and loosen authority than the other governors of the Sikh state ${ }^{28}$. Avitabile replicated there his Wazirabad government style: in the first place a huge construction program was started, for both civil and military buildings. The city was almost rebuilt in a new modern fashion ${ }^{29}$, according to European principles of order: streets were widened and a new bazar was built along with a mud wall surrounding the city ${ }^{30}$. Bridges and roads were improved and went under maintenance.

14 The collection of the revenue and the general administration of the state were also improved. Avitabile used to collaborate with the former rulers of the province (the Barakzais of Peshawar) to exploit their know-how of the province social and economic situation and also to legitimize his rule, maintaining continuity with traditional institutions. He introduced also some improvements. Despite we have no clue that he replicated the record books-system he started in Wazirabad, we know that he introduced a fixed-rate tax, to be paid in silver, instead of the payment in goods ${ }^{31}$. Several sources prove that under Avitabile the income of the province grew steadily, surpassing that of the Durrani age ${ }^{32}$.

15 This apparently excellent governorship makes us wonder how it was possible to build up such a negative fame on Avitabile. The answer lies in the last fields of his rule: justice and relations with the neighbouring Peshawar tribes. being looked at more closely. Firstly it is important to underline how Avitabile 
regarded the judicial activity as the most important of his tasks as governor: he used to hold Durbar (justice council) almost every day ${ }^{33}$. As it has already been said, the Sikh rule over the city was hardly tolerated by the Muslim population. The Pashtun lost no occasion to rob or even assassinate the Sikhs, soldiers and civilians ${ }^{34}$. This situation, with the presence of various ethnic groups, each one with peculiar religion, laws and customs, could easily degenerate in open riot or turmoil every time. The absence of any form of written law complicated the task of Avitabile even more ${ }^{35}$.

The solution provided by the Italian governor was a strict application of the traditional law customs of the province, wisely balanced by the advice of some counsellors. Avitabile's Durbar was composed of Muslim Qazis (judges), Hindus and Sikh judges ${ }^{36}$. With the collaboration of these advisors Avitabile was able to use the different law traditions of the province wisely. In particular the Islamic one was clearly the most important among them and was the basis of Avitabile's judicial action ${ }^{37}$. This law was by no means mild, with a large use of death penalty and mutilation for theft and robbery as well as for homicide ${ }^{38}$. By these means, in the field of civil justice, Avitabile earned the fame of wise judge ${ }^{39}$. In the criminal justice the strict use of the Islamic law, backed by an extremely efficient police action, provided a radical decrease in the criminal rates ${ }^{40}$. A number of gallows were erected outside the city walls to host the victims of Avitabile's repression of the city criminals ${ }^{41}$. But thieves and assassins from the city of Peshawar were not the only ones who met their fate on the gallows: also many members of the tribes of the surrounding hills were among them.

Ethnically Pashtuns and faithful Muslims, those tribes lived in a mountainous and harsh territory in a semi-nomad style of settlement, conducting frequent raids on the plain and the city ${ }^{42}$. No government had previously managed to claim control of these lawless and fierce tribes and their valleys. Both the Mughals and the Durranis governors claimed only nominal sovereignty on them. Avitabile's task was not different, but further complicated by the religious animosity of the tribes against the Sikhs. His action was as harsh as the situation he had to deal with: nominal sovereignty was claimed by the collection of revenue from the tribes, by means of military expeditions ${ }^{43}$. The frequent raids (both for kidnapping hostages and to sack cultivations) on the plain were stopped by a severe restraining of the tribal presence in Peshawar proximities: tribesmen were allowed to reach the city only to purchase specific goods; in any other case, if found near the city, they were hastily hanged ${ }^{44}$. The gallows outside the city wall were, by these means, always plenty of corpses, acting as an efficient deterrent ${ }^{45}$. As in the administration of justice, in his relation with the neighbouring tribal Peshawar population, Avitabile did not distance himself from local traditions, making no difference with the actions of his Mughal or Durrani predecessors. The only 'trademark' of Avitabile was his extreme efficiency and harshness, with a consequent much greater bloodshed than in the past.

The last years of Avitabile as governor of Peshawar were even more complicated because he had to deal with the concurrent First Anglo-Afghan War. Avitabile was thus heavily involved in all the phases of the war, giving an invaluable aid to the British forces, despite some tensions with the EIC political officers ${ }^{46}$. At the same time of his participation to the Afghan War, and in particular in 1841, Avitabile had also to cope with the chaotic situation of the Punjab which followed the struggle for the succession to Ranjit Singh's throne ${ }^{47}$. In particular the mutiny of his Sikh troops in June 1841 was 
one of the main events that forged the 'black legend' of Avitabile is about to be examined.

This image of Avitabile as a cruel, ruthless and almost sadistic ruler has been largely established by his two biographers. The former was Julian James Cotton, author of the first wide-known biography of the Italian adventurer: Life of General Avitabile (1905); the latter was Charles Grey, author of the biography collection European Adventurers of Northern India 1785-1849 (1929). However, these two authors did not built this black legend by themselves, rather their works fixed an image that the sources (mainly travellers' memoirs and British officers' correspondence and autobiographies) were drawing almost from the 1840 's. Before examining the works of Cotton and Grey, it is fundamental to analyse these sources, an analysis not without surprises. This analysis will proceed chronologically, to better appreciate the progressive sedimentation of the different sources (each one with his own opinion on Avitabile) used by the two authors. The first group of sources which have been used by the biographers (mainly by Grey) is the correspondence of the British officers that resided in Peshawar before or during the First Afghan War. The tone of the correspondence changes noticeably when new officers take on the task. The first of them was Colonel C.M. Wade, who was chief of the Ludhiana Agency for many years (often visiting the Punjab and Ranjit's court) and stayed in Peshawar many times until spring 1840. He was mainly concerned with his diplomatic and military duties and did not pay attention to the details of Avitabile's rule in the Pashtun city. This is true in particular for his most known correspondence, written during the organization of the Anglo-Afghan expedition in $1839^{48}$. He appreciated the military and logistic aid offered by Avitabile and also his ability and knowledge in the transactions with the Khyber tribes. Moreover he did not criticize the Italian judicial activities, as long they eased the expedition.

Avitabile's relations with the next officer, Frederick Mackeson, were far less simple and changed substantially with the passing of time. Mackeson's assistants in that period were two officers who were to have important careers and whose literary works were to have a great part in the formation of Avitabile's black legend: Colin Mackenzie and Henry Montgomery Lawrence. The early relations between Mackeson and Avitabile were far from friendly: during 1840 Mackeson, along with Macnaghten (the British resident in the newly-conquered Kabul), made strong complaints to the EIC's government in Calcutta regarding Avitabile's conduct ${ }^{49}$. In particular the argument was Avitabile's harsh politic against the Pashtun tribes of the hills: Mackeson and Macnaghten strongly criticized the practice of the military expedition to collect revenues among the tribesmen. Avitabile replied accusing Afghan representative of instigating raids with the tribesmen. The diplomatic affaire caused by these complaints worsened to such an extent that Calcutta asked Lahore the removal of Avitabile ${ }^{50}$, before the mediation of George Clerk (the new Ludhiana Agency Chief Agent) and a change of mind by Mackeson settled the question ${ }^{51}$. Surprisingly, what we can notice from the sources is that Avitabile's violent proceedings were never the argument of concern. Mackeson and Macnaghten protested because they considered the tribesmen to be subject to Kabul authority due to the not strictly defined border between Punjab and Afghanistan and to the nomad lifestyle of the tribes. The issue was the fact, not the manners. Again this fact leaves us with the question about how Avitabile's image took this negative shape. 


\section{mentioned above was solved, the relations between Mackeson and Avitabile improved steadily. Moreover, Mackeson and Clerk made known to the Calcutta government that Avitabile's ability to deal with mutinous Sikh troops in spring 1841 was essential to protect the EIC's communication and logistic lines with Kabul ${ }^{52}$. In particular Avitabile repressed a dangerous mutiny between his Sikh troops with unorthodox methods: he made an agreement with the same Pashtun tribes that he had long fought to make them attack the mutinous troops that had threatened his life and that of the British officers $^{53}$. Even Lord Auckland (the Governor-General of India) agreed that with this move Avitabile prevented the degeneration of the condition of the whole Punjab ${ }^{54}$.}

the Italian and the British officers. In fact from June 1840, when the diplomatic affaire

Furthermore, in the following months Mackeson made diplomatic pressure on Avitabile to prevent him from resigning, regarding his efficient presence as vital for the British interest in the $a r e a^{55}$. He proved to be right when, after the British crisis of 1841 winter in Afghanistan, Avitabile's actions and presence were essential to prevent an attack from the Pashtun tribes on Peshawar that would have meant the collapse of the British position in Afghanistan. Furthermore, Avitabile led his troops on the field during the Anglo-Sikh attack on the Khyber Pass ${ }^{56}$.

In the following years, when Avitabile returned to Europe, he was aided by the EIC in securing his conspicuous wealth and was warmly welcomed in London by the Company's high representatives ${ }^{57}$. So how could the British historians have created the image of the villain Avitabile?

\section{The building of a 'black legend'. Travellers and officers memoirs}

The answer lies in the memoirs about Avitabile of the officers and travellers who met him in Punjab, and, to be more specific, in the radical change that we can observe among those memoirs during the following years.

The best known among the first officers who left a description of Avitabile in their memoirs is certainly the famous Alexander Burnes. In his posthumous narrative about his diplomatic mission from India to Kabul, the Scottish officer described both his encounter with Avitabile at Peshawar and the city, with particular attention to the governorship of Avitabile. He praised Avitabile's 'active mind' and his measure 'to improve the town and tranquillize the neighbourhood ${ }^{38}$, including the harsh repressive policy both against the tribesmen and the most seditious citizens. In Burnes' words we find the conviction, shared by many others British officers that: 'although at first his [Avitabile's] measures appeared to us somewhat oppressive, his proceedings were, I am sure, in the end, more merciful than if he had affected greater lenity ${ }^{59}$. As already said, other British officers expressed similar thoughts in their memoirs. William Barr, in his account of the Anglo-Afghan war, wrote:

The blood-thirsty disposition of the Afghans is but too manifest in the number of gallows that it has been deemed necessary to erect in the environs of the city. [...] But, disgusting as these exhibitions are, it is to be feared that without them there would be safety neither for life nor property. Indeed, the benefits of this terrible severity is already [sic] being felt ${ }^{60}$. 
tone is present also in the accounts about Peshawar written by other British officers, in particular Henry Havelock ${ }^{61}$, Daniel Mackinnon ${ }^{62}$ and Henry Marion Durand $^{63}$. In the same way as Barr, they admit that Avitabile's measures are literally draconian, but they justify them with the necessity of subduing such a rebellious and savage population as the Afghan Pashtuns were. A less severe conduct by the Italian governor would have caused major bloodshed than the one procured by his harsh law and police measures. The reason of the approval granted by these men to Avitabile's repressive policy is clear: they shared the Neapolitan's formation and attitude. They were the late representatives of the generation of the East India Company officers who built the British Raj in India: though often employed as governors (and seldom as diplomats) they were mainly soldiers ${ }^{64}$ Ruthless and pragmatic, they were not guided by reform ideals, being rather interested in maintaining public order and winning on the battlefield. They could see themselves in the same role as Avitabile and shared his views in matters of law and order. The most cultured and brilliant among them, Burnes, went further in his analysis of Avitabile's governorship, stating that 'the General did not pretend to be guided by European ideas' ${ }^{\prime 65}$. He recognized that the matter was not only strictness, but also adapting to local traditions, a conduct that Avitabile and many of his predecessors (both EIC's officers and adventurers) probably followed instinctively.

An opinion similar to that of the British officers that we can call the 'old generation' is expressed by a number of travellers who met Avitabile in different periods of his service in India. They were fascinated by Avitabile and his personality, and expressed positive opinions on his governorship, dismissing his harsh penal system as the least evil ${ }^{66}$.

This lenient and even positive view on Avitabile and his governorship began to change with the new generation of British officers that met Avitabile during the First Afghan War. The most famous is certainly Henry Montgomery Lawrence, who served as assistant of Mackeson in the last months of the war. A young officer with a good cultural competence, Lawrence used his knowledge of the European adventurers of Ranjit Singh to write a semi-biographic novel, Adventures of an Officer in the Paunjab, in which Avitabile is described. The Neapolitan is praised by Lawrence for his talents as a governor $^{67}$, but the British author then describes the harsh repression at Peshawar in a much more negative tone than his predecessors:

Under his rule, summary hangings have been added to the native catalogue of punishments, [...] the ostentation of adding two or three to the string suspended from the gibbet, [...] added to a very evident habitual carelessness of life, lead one to fear that small pains are taken to distinguish between innocence and guilt ${ }^{68}$.

Lawrence ground of complaint is clear: despite he had to 'consider him [Avitabile] as set in authority over savage animals - not as a ruler over reasonable beings', he should not have acted 'as a savage among savage men instead of showing them that a Christian can wield the iron sceptre without staining it by needless cruelty - without following some of the worst fashions of his worst neighbours' ${ }^{69}$. Lawrence view is clear: a European should reform the native barbarous customs and laws, instead of adopting them. Rather than this, 'Avitabili's [sic] whole system of morals is Oriental, [...] looking on subjects as made to be squeezed ${ }^{70}$. The last opinion on Avitabile sounds like an absolution, but the blame for his sins remains:

He has, at the expense of his own character for humanity, by the terror of his name, saved much life. [...] the peaceful and well-disposed inhabitants of Peshawar, both 
Hindoo and Mahomedan, united in praise of his administration, [...] Believed to fear neither man nor devil, Avitabili [sic] kept down by grim fear what nothing else would keep down - the unruly spirits around him, who, if let slip, would riot in carnage; his severity may therefore be extenuated as the least of two evils ${ }^{71}$.

\begin{abstract}
The other assistant of Frederick Mackeson, Colin Mackenzie, took a step further in criminalizing Avitabile's figure. Before analysing Mackenzie's memoirs, it must be borne in mind that he was not strictly their author. Edited after his death, they were revised by his widow who was an experienced writer, and may have further exacerbated the gruesome particulars which are common in Avitabile's description.
\end{abstract}

The image of the Italian adventurer depicted by Mackenzie is negative from the beginning. He admitted that Avitabile was skilled and probably the best governor in Punjab, but immediately he called him cruel, unscrupulous and corrupted:

He [...] certainly keeps his province in better order than any other Sikh governor.

[...] He is evidently a man of great talent and dauntless determination, but capricious, somewhat cruel, and most unscrupulous in increasing his already large fortune by heavy fines, which are the perquisites of the Governor ${ }^{72}$.

Avitabile's wealth was definitely blamed by Mackenzie, in particular the 'Oriental' pomp of his house ${ }^{73}$. The British officer never failed to mention the dubious provenience of Avitabile's money and the circumstance that in Peshawar almost every crime could be repaid under the form of a fine $\mathrm{e}^{74}$. What was not accepted or understood by Mackenzie was the need for Avitabile to legitimize his power with the adoption of a luxurious appearance, associated by the local population to political power and the retribution character of the Islamic law applied by him. In this context we can better understand Mackenzie's bloody tales about the correspondence of private vengeance and public justice in Avitabile's Peshawar ${ }^{75}$. Mackenzie's tale of his months at Peshawar is full of such gruesome anecdotes about Avitabile's governorship and in particular justice as the famous story of the man thrown off a minaret, or of the bricked-alive Afghans ${ }^{76}$, but only seldom noticing that such cruel punishments were far from unusual in Central $\mathrm{Asia}^{77}$. For the Christian spirit of Mackenzie the exhibited atheism and scepticism of Avitabile were even more scandalous, if not the cause of his excesses ${ }^{78}$.

About the most famous of Avitabile's unorthodox actions, the repression of the mutiny among his Sikh troops (during which Avitabile in fact saved Mackenzie and Mackeson's lives), the British officer provides in this memoir many creepy details about the Italian's behaviour and blood-thirstiness ${ }^{79}$. However, these details, it must be pointed out, were not included in his otherwise extremely detailed official report to the Ludhiana Agency.

As a final blow to Avitabile's figure, Mackenzie underlined how the Italian's measures changed by the enlightened influence of British officers like him ${ }^{80}$.

7 Summing up, to all intents and purposes, Mackenzie description of Avitabile resembles that of an 'Oriental Despot'. The Italian's fault looks even more serious because in Mackenzie's mind a European should not act like that. But what is the reason of this progressive criminalization of Avitabile's image by these two late witnesses ? The answer is simple.

Lawrence and Mackenzie were part of a new generation of EIC's officers, who saw the British rule in India as a 'civilizing mission': formed on James Mill's History of British India, they sensed what would be called 'the white man's burden', the moral obligation to reform the extra-European societies, considered barbarous and uncivilized. These 
men were to form the bulk of the functionaries who built up British India after the Great Mutiny in 1857, as well as being the greatest part of the Victorian Age historians. This generation left little room for comprehension or appreciation of a man like Avitabile, who adapted his governorship to the native customs for a stronger effectiveness.

Unfortunately for Avitabile's fame, the primary source for his first biographer, Julian James Cotton, was not Lawrence severe but however balanced opinion, but Mackenzie's harsh judgment and gruesome anecdotes.

\section{The building of a black legend. The historiography}

The Life of General Avitabile by J.J. Cotton is the first, the most important, and also the most influential biography of the Neapolitan adventurer, but it is not the first historiography work to speak about him. Before analysing Cotton's book, we should briefly speak of the previous appearances of Avitabile in the Victorian historiography. The first historians who spoke about Avitabile were those who narrated the history of the Sikh Kingdom of Punjab or that of the First Afghan War. These were Joseph Davey Cunningham in his History of the Sikhs ${ }^{81}$, John William Kaye in the monumental History of the War in Afghanistan ${ }^{82}$ and Henry Marion Durand (the only one who met Avitabile) in The First Afghan War and Its Causes ${ }^{83}$. All these works have in common a rather neutral, if not openly positive, view on general Avitabile. The Neapolitan is regarded mainly as a professional soldier, his governorship in Peshawar is only superficially considered and the main concern of the authors is to underline the aid given by Avitabile to the British cause in Afghanistan. The reason of this positive view lies in their sources: their works are based on the first group of memoirs analysed above, which shared a good image of the Italian adventurer.

41 The first historian who gave rise to the black legend of Avitabile was Herbert Edwardes in his posthumous Life of Henry Lawrence. Having been the personal secretary of Henry Lawrence, Edwardes shared his senior views on colonialism and in the few pages he dedicated to Avitabile he built a decisively negative image of the Italian. Though Edwardes recognized Avitabile's genius in government, he also stressed his 'oriental cunning', his lack of morality, and, even more serious, of religious faith ${ }^{84}$. Avitabile's only concern, in Edwardes' narration, is to return to Europe with his fabulous wealth: a reason for which he helped, or better he exploited, the British during the Afghan war. In few words, this was the portrait of a real evil-genius. Another Victorian biographer of Lawrence, F. Gibbon, is more concise, stating that: 'Avitabile, the brutal Italian soldier of fortune, had ruled by fear alone ${ }^{\prime 85}$. It is easy to notice here how the admirers of Lawrence 'Christian spring of action' could not have a positive opinion of Avitabile's pragmatic governorship.

So it is possible to realize how Avitabile's black legend was already in formation between memoirs and historiography when J.J. Cotton wrote his biography of the Italian adventurer. Born in India of British parents, Cotton was a functionary of the British Empire in Madras, like his father before him. He married a Neapolitan woman and, during the months he spent in Naples, he did the researches for his Life of General Avitabile. Despite claiming to have consulted a diary of the General which is now lost, in Cotton's work there is nothing that is not already present in Camera's short biography or in previous memoirs. An exam of this Life of Avitabile reveals how Cotton was not 
truly interested in writing a rigorous historiography work, but rather in representing Avitabile as a half-fictional character. For his purpose, Cotton amassed without much continuity or method any story he found and deemed curious, interesting or shocking. Because he relied massively on Mackenzie's gruesome and negative anecdotes, the result is that the Neapolitan took the features of the villain from a Gothic novel. Cotton also derived information from secondary memoirs which contains rather unlikely (even for him) particulars about Avitabile, like those of Gardner or Honigberger ${ }^{86}$. In the same way, the author grants great room to the totally unconfirmed legend that figures Avitabile dying poisoned by his young and unfaithful wife ${ }^{87}$. However, Cotton reserved also much space to positive opinions about Avitabile and his Peshawar governorship and showed a sort of sympathy for this man who liked the pleasures of life as well as admiration for the fearless governor who tamed the Afghans. But, despite Cotton did not condemn Avitabile in the book, the (maybe accidental) result of his more literary than historic work is to strengthen permanently the image of Avitabile as a cruel, blood-thirsty and evil adventurer.

After Cotton's biography, it was the chapter about Avitabile included in Charles Grey's European Adventurers of Northern India that ultimately strengthened the Italian's 'black legend'. After a short introduction in which he praises Avitabile's energy and ability as a governor, Grey reworked Cotton's narration, the memoirs and also the archive sources to build an image of the Neapolitan as negative as he could. Grey stated that 'his nature was cruel, and his moral worse' ${ }^{88}$, depicting also Avitabile as a greedy and vicious man. In Grey's words there is no room for the empathy shown by Cotton. Even when he tried to find mitigating circumstances for Avitabile's behaviour, Grey did it with an embarrassing display of chauvinist and racist stereotypes about Italians, Indians, Sikhs, Persians and, more than anyone, Afghans, whom he regarded as violent and barbarous populations ${ }^{89}$. To destroy Avitabile's image he recalled even Honigberger's opinion about the alcoholic-caused madness of the Italian, regarded as unlikely even by Cotton ${ }^{90}$. Grey even invented a supposed refusal by Lord Ellenborough to meet Avitabile, an event contradicted by their friendly correspondence about Avitabile's wealth ${ }^{91}$. To conclude his monstrous portrait of the Neapolitan adventurer, Grey states: 'Whatever the manner of his death, none can say that he had not merited a violent one, for the number he had sent before him by such means is incredible and undoubtedly, all did not deserve it ${ }^{\prime 92}$.

In the following decades the works of Cotton and Grey about Avitabile influenced every author and historian dealing with the history of the Punjab Kingdom, the First Afghan War or the Peshawar region ${ }^{93}$. Indian post-colonial historiography accepted apparently uncritically this "black legend"94. Even faultless authors such as Olaf Caroe used this stereotyped image in their work ${ }^{95}$. The fortune of the black legend about Avitabile spread also in French historiography ${ }^{96}$ and endures today in popular books such as the recent Khyber Pass. A History of Empire and Invasion by Peter Docherty ${ }^{97}$.

Only in recent years academic works have reinstated Avitabile's image to a more balanced view: in particular Jean-Marie Lafont's monumental work on the 'French officers of Ranjit Singh' shines a new and rigorous light on the Italian adventurer's life ${ }^{98}$.

46 And what about Avitabile's homeland historiography? Italian biographies about the Neapolitan adventurer are few and scattered over the decades. Moreover, only Camera's brief narrative appears not to rely on the British colonial works, but rather to 
be probably one of Cotton's sources. On the field of their interpretation of Avitabile's role and career, they struggled to turn the tide of the 'black legend' created in the Victorian Age, but their attempt is so excessive in trying to make Avitabile a hero that it is even more misleading 99 .

\section{Conclusion}

All considered, we can conclude affirming that the evolution, or better the progressive criminalization of Avitabile's figure was a consequence of the evolution that we can observe among the British officers who met him and left a description of him in their memoirs. While the first of them (like Burnes and Barr) were pragmatic soldiers interested mainly in succeeding in their military and civil tasks, more or less like Avitabile, the latter (like Lawrence and Mackenzie) were reformers who believed in the civilizing mission of the 'white men'. Formed on James Mill's History of India, to their eyes Avitabile's adoption of the native laws and customs was unforgivable. Victorian historians progressively adopted this negative vision of the Italian adventurer, as long as new memoirs full of gruesome anecdotes were published: for literary purposes (Cotton) or because they had become deeply rooted in the above mentioned colonial mentality (Edwardes, Grey).

But ultimately, who was Avitabile? Sources suggest that he was simply a soldier that, like his more renowned predecessor Benoit De Boigne, seeing no chance of career in his homeland sought it in the fabulous Orient. Once he found an assignment he worked hard and pragmatically (and also without many scruples) to get his tasks accomplished and return to Europe with the profits of his career. But the surest thing about Avitabile lies in these words from Henry Montgomery Lawrence: 'Strangely influencing those around him, and influenced by them, Avitabile's history is a curious study, and, when his own generation has passed away, will hardly be believed' ${ }^{\prime 100}$.

\section{NOTES}

1. On the first European victories over the post-Mughal states, and the first phase of European expansion in India, cf. M. TORRI, Storia dell'India, Laterza, Roma-Bari 2000, p. 332-341.

2. On the military modernization of the Indian native states see P. BARUA, 'Military Developments in India, 1750-1850', The Journal of Military History, vol.58, No. 4 (Oct., 1994), p. 599-616; K. RoY, "Military Synthesis in South Asia: Armies, Warfare, and Indian Society, c. 1740-1849", The Journal of Military History, vol. 69, No. 3 (Jul., 2005), p. 651-690. On the traditional Indian warfare dating back to the Mughal era, see J. GOMMANs, Mughal Warfare. Indian frontiers and High Roads to Empire: 1500-1700, Routledge, London and New York 2002.

3. For a general account on the 18th century's adventurers see S. BIDWELL, Swords for hire: European mercenaries in eighteenth-century India, John Murray, London 1971; P. LE TREGUILLY, "Les Aventuriers", in P. LE TREGUILLY, M. MORAZE (dir.), L'Inde et la France, deux siècle d'histoire commune, Paris, Éditions du CNRS, 2006, p. 51-63. 
4. A study on the modernization of both the Marathas and the Mysore can be found in K. ROY, War, Culture and Society in Early Modern South Asia, 1740-1849., Routledge, New York-London 2011.

5. P. LE TREGUILLY, “Les Aventuriers”, op. cit., p. 53-54.

6. Ibid., p. 62-63.

7. On the Sikh Empire of Ranjit Singh see, among others, KHUSWANT SINGH, A History of the Sikhs, I, Oxford, Oxford University Press 1999; J.S. GREWAL, The Sikhs of the Punjab, Cambridge, Cambridge University Press 1990. On the Sikh military modernization, see K. ROY, "Technology and transformation of Sikh warfare: Dal Khālsā against the Lāl Paltans, 1800-1849”, Indian Journal of History of Science, 41, 4, 2006, p. 383-410. On the European adventurers in the service of the Sikh Empire, see the classic C. GREY, European Adventurers of Northern India. 1785-1849, Lahore 1929; and the recent excellent study J.M. LAFONT, La présence Francaise dans le Royaume Sikh du Penjab. 1822-1849, Paris, EFEO 1992. On the interesting figure of Ventura see M. P. BALBONI, Ventura. Dal ghetto di Finale alla corte di Lahore, Modena, Aedes Muratoriana 1993. On Avitabile the fundamental biography is James J. cotTon, Il generale Avitabile, Napoli, Tip. Trani 1907 [ed. orig. Life of Generale Avitabile, Calcutta Review 1905, p. 520-586].

8. Almost all the adventurers exercised their activities as private individuals, so there is almost no source about them in the official archives. Furthermore they were only seldom instructed, leaving very rarely memories about their careers. The main works about them date back to the early $20^{\text {th }}$ century: H.G. KEENE, Hindustan under free lances (1770-1820): Sketches of Military adventure in Hindustan during the period immediately preceding British occupation, London, Brown\&Langham 1907; M. BESSON, Les aventuriers français aux Indes 1775-1820, Paris, Payot, 1932.

9. The main source about the first years of Avitabile's life and service (until his discharge in 1816) is a small biography from a local historian from Salerno, named Matteo Camera. In his work about the history of the city of Salerno and its surroundings, Camera speaks briefly of Avitabile's life and career. Despite his shortness, Camera's account on Avitabile is very precious, and seems to be the principal source of Julian James Cotton, the most famous of Avitabile's biographers, when he narrates the first years of the Neapolitan adventurer. M. CAMERA, Memorie storicodiplomatiche dell'antica città e ducato di Amalfi [1881], Salerno 1972, p. 637-644.

10. This Convention regulated the reorganization of the Neapolitan Army following the return of the Bourbon dynasty. Its articles were a big disadvantage of the officials who, like Avitabile, served under Joseph Bonaparte and Murat. L. BLANCH, Scritti Storici, II, Il Regno di Napoli dalla restaurazione borbonica all'avvento di Re Ferdinando II (1815-1830), Bari, Laterza 1945, p. 58-59.

11. The Persian period of Avitabile's career is rather obscure. The biographers tell us only a few details, and no source has yet been found in the British or in the Persian archives. The few details we possess are provided by Grey and Cotton. On Avitabile Persian period, cf. GREY, European Adventurers, op. cit., p. 120-122; James J. COTTON, Il Generale Avitabile, op. cit., p. 18-22.

12. An interesting account of this voyage is provided by Avitabile's travel companion and comrade, Claude-Auguste Court. Filled with many observation and reports on the countries they visited, it was published in the appendix of Grey's work on the adventurers, cfr. GREY, European Adventurers, op. cit., p. XVII-XLVIII.

13. For the few information about Avitabile's first years in the Punjab and his military career cfr. GREY, European Adventurers, op. cit., p. 122-124; LAFONT, La présence française, op. cit., passim.

14. On Avitabile's career as a civil governor, cf. LAFONT, La présence française, op. cit., p. 190-199 et passim.

15. On Avitabile's participation to the First Afghan War, cfr. Ibid., p. 420-432.

16. The correspondence of the EIC's officers is mainly held in the India Secret Proceedings and in the Enclosures of Secret Letters from India in the India Office Records at the British Library (London). The memoirs will be analysed in the afterwards of this article. 
17. The presence of a man of such adventurous and exotic past created some turmoil in the peasants of Agerola. Furthermore, many rumours suggest that Avitabile was poisoned by his wife; however there is no evidence that confirms this story. Cf. James J. COTTON, Il Generale Avitabile, op. cit., p. 81-85 ; G. PINGUETINI, Un Contadino Napoletano Viceré in India. Il Generale Paolo Avitabile, Malta 1951, p. 46-48.

18. Only a few hints, but no numeric records, could be found in SITA RAM KOHLI, Catalogue of Khalsa Darbar Records, vol. I, Lahore 1919, passim.

19. For details of the military campaigns of the French officers of Ranjit Singh, see J.M. LAFONT, Fauj-i-khas: Maharaja Ranjit Singh and his French Officiers, Guru Nanak Dev University 2002.

20. During his years in Persia Avitabile exercised some kind of civil authority, probably in Kurdistan region, but no other detail on those events is available. GREY, European Adventurers, op. cit., p. 122.

21. The Italian Governor introduced a new system for the collection of revenue: instead of the traditional payment in goods or spices, he introduced a fixed rate of one third of the agricultural income, to be paid in silver. AA. VV. Punjab District Gazetteer Sialkot, 1935, p. 24, op. cit. in LAFONT, La présence française, op.cit., p.192. To control effectively the revenue collection and prevent corruption Avitabile also introduced a system based on books of receipts in the villages. A. RAYNOR, H.R. GOULDING, Selections from the Punjab Government Records, Diary of H.B. Edwardes $-22^{\text {nd }}$ February 1847, vol. V, Political Diaries of H.B. Edwardes, Lahore 1915, p. 17-18. Also commerce and finance were encouraged, cf. A. RAYNOR, H.R. GOULDING, Selections from the Punjab Government Records, Diary of R.G. Taylor $-16^{\text {th }}$ May, vol. VI, Political Diaries: R.G. Taylor, J. Nicholson and others 1847-49, Lahore 1915, p. 2.

22. For an example of Avitabile dealings with the different local traditions in matters of justice, see J. M. HONIGBERGER, Thirty-Five Years in the East, London 1852, p. 55. On the respect of religious tradition and customs, see B. N. GosWAMI, "General Avitabile and the Vaishnava establishment at Dhyanpur", in Journal of the Royal Asiatic Society of Great Britain and Ireland, N. 2 (1971).

23. AA. VV. Punjab District Gazetteer - Gujranwala District, Punjab Government Record Office, Lahore 1935, p. 348.

24. Among them there was Maharaja Ranjit Singh, who permanently controlled the activities of his generals, officials and governors. Cfr. SOHAN LAL SURI (translated by V.S.SURI), Umdat-utTawarikh, III, S. Chand \& co. 1961, p. 211. Between the European travellers who pleaded Avitabile's governorship, we remember as example the Rev. Joseph Wolff.

25. SOHAN LAL, U.T., III, op. cit., p. 236-237, p. 250-252, p. 263, p. 271.

26. Ibid., p. 283.

27. Ibid., p. 359.

28. FAUJA SINGH, "Territorial Organization: Concept of state rule and distribution of power", in J. S. GREWAL, INDU BANGA (eds.), Maharaja Ranjit Singh and his times, Guru Nanak Dev University, Amritsar 1980, p. 96-97.

29. H. G RAVERTY, "Account of the city and province of Peshawar", Transactions of the Bombay Geographical Society, vol. X (Sept. 1850 - Jun. 1852), Bombay 1852, p. 15.

30. For a contemporary account on Avitabile's renewal of Peshawar, see SHAHAMAT ALI, The Sikh and Afghans. In connection with India and Persia, immediately before and after the death of Ranjeet Singh, John Murray, London 1847, p. 258-261. For a modern study, see A.H. DANI, Peshawar Historic City of the Frontier, Khyber Mail Press, Peshawar 1969.

31. AA. VV., Gazetteer of the Peshawar District, 1897-98, Sang-e-Meel Publications, 1989, p. 75.

32. AA. VV. Imperial Gazetteer of India, vol. XX, Clarendon Press, Oxford 1907, p. 121.

33. Akhbarat-i-Sikhan, in Journal of the Punjab University Historical Society, X (1937), p. 50-79.

34. SHAHMAT ALI, Sikh and Afghans, op. cit., p. 279-281. H. HAVELOCK, Narrative of the War in Afghanistan in 1838-1839, vol. II, Henry Colburn, London 1840, p. 200. 
35. During his Peshawar governorship, Avitabile tried to solve this problem, ordering a written collection of local laws to be draught. However, no sign of this "code" remains today. LAFONT, La présence française, op. cit., p. 197-199.

36. H. M. DURAND, Life of Major-Generale Sir Henry Marion Durand, W.H. Allen, London 1883, p. 63.

37. Applied in India since the time of the Delhi sultanate, it was the only written law if the subcontinent. For an overview on the connection between Mughal and original Islamic law, see J. FISCH, Cheap Lives and Dear Limbs. The British Transformation of Bengal Criminal Law, Steiner 1983, p. 13-24. Unlike the British reformers of the EIC, Avitabile never intended to reform the penal justice of the country he governed. He restricted his action to pragmatic improvements, such as readiness and certainty of the penal justice.

38. It carried since its birth a character of "blood retribution" that explains its extreme sternness. For an example of this tendency in Avitabile's experience, see C. MACKENZIE, Storms and Sunshine of a Soldier's Life, vol. I, Douglas, Edinburgh 1884, p. 146.

39. In particular for his habit of administering justice in first person, cf. RAVERTY, "Account of Peshawar", op. cit., p. 15. Moreover, there is evidence that Avitabile fought the practice of sati, cf. HONIGBERGER, Thirty-five Years, op. cit., p. 55.

40. SHAHMAT ALI, Sikhs and Afghans, op. cit., p. 279-280.

41. DURAND, Life of Durand, op. cit., p. 62-63.

42. A. RAYNOR, H. R. GOULDING, Selections from the Punjab Government Records, Diary of P. Lawrence, 2nd April 1848, vol. IV, Journals and Diaries of the Assistant to the resident at Lahore 1846-1849, Lahore 1915, p. 465-466.

43. MACKENZIE, Storms and Sunshine, op. cit., p. 145.

44. A. RAYNOR, H. R. GOULDING, Selections from Punjab Records, Diary of P. Lawrence, 1st March 1848, vol. VI, op. cit., p. 453-454.

45. The tribesmen no longer raided the plain during Avitabile's government. Cfr. MACKENZIE, Storms and Sunshine, op. cit., p. 145.

46. Peshawar was a strategic location for the war, being situated at the mouth of the Khyber Pass, one of the two main routes that from the British India led, through the Punjab, to Kabul. In 1839 he gave logistical as well as military support to the Anglo-Afghan secondary expedition that from Peshawar marched to Kabul. During the period 1840-1841 he was at the core of the difficult coexistence between the Sikh state and the new Afghan kingdom, both allied with the EIC. And in the last phase of the war, which followed the British disaster at Kabul in the 1841-1842's winter, he helped the EIC's army to reorganize and force the Khyber Pass. On the First Afghan War, see J. A. NORRIS, The first Afghan war 1838-1842, Cambridge, Cambridge University Press 1967. On Avitabile's relations with English officers in matters of war, see B. J. HASRAT, Anglo-Sikh Relations 1799-1849, Horsiapur 1968.

47. For an account of the last, troubled years of the Punjab Kingdom, see SITA RAM KOHLI, Sunset of the Sikh Empire, Orient Longmans, New Delhi 1967.

48. Wade's correspondence during those months is huge. Transcriptions of the most part of letters can be found in the British Library, India Office Records, India Secret Proceedings, vol. 21-23. Abstracts of the correspondence with the Ludhiana Agency and Avitabile could be found in AA. VV., Calendar of Persian Correspondence. Abstracted into English, vol. III (Jan-Jun 1839), Punjab Archives, Lahore; AA. VV., Press Lists of Old Records in the Punjab Cil Secretariat, vol. V, Ludhiana Agency. Miscellaneous correspondence, 1816-1840, Punjab Record Office, Lahore 1915; AA. VV. Press lists of old records in the Punjab Civil Secretariat, vol. VI, Ludhiana Agency. Correspondence with Government, 1831-1840. Lahore, Punjab Record Office 1915. However, Wade's difficult character brought him to be relieved from his position at the end of the campaign.

49. Transcriptions of the diplomatic exchange on this matter are in British Library, India Office Records, India Secret Proceedings, vol. 43, 14 $4^{\text {th }}$ September 1840 (nn. 82-83). Abstract can also be 
found in AA. VV., Press lists of old records in the Punjab Civil Secretariat, vol. VII, North-West Frontier Agency. Correspondence with Government. 1840-1845. Punjab Record Office, Lahore 1915; AA. VV., Press lists of old records in the Punjab Civil Secretariat, vol. VIII, North-West Frontier Agency. Miscellaneous Correspondence. 1840-1845, Punjab Record Office, Lahore 1915.

50. FAUJA SINGH, Kharak Singh, Torrens to Clerk, $1^{\text {st }}$ June 1840, op. cit., p. 231-233.

51. Ibid., p. 295-296.

52. In particular during the passage of the Anglo-Afghan kafila (caravan) under Maj. Broadfoot, transporting the Afghan royal family to Kabul. See AA. VV., Punjab Secretariat Press Lists, vol. VIII, op. cit., p. 646-647. For a reconstruction, HASRAT, Anglo-Sikh Relations, p. 206-208.

53. Mackeson to Clerk $-10^{\text {th }}, 11^{\text {th }}$ June 1841 , British Library, India Office Records, India Secret Proceedings, vol. 58, $5^{\text {th }}$ July 1841 (nn. 97-98).

54. Auckland to Hobhouse $-7^{\text {th }}$ July 1841, British Library, Addicted Manuscripts, Auckland Letters, AM 37705, fol. 152.

55. AA. VV., Punjab Secretariat Press Lists, Clerk to Mackeson - $5^{\text {th }}$ July 1841 , vol. VIII, op. cit., p. 653.

56. Lawrence to Clerk $-5^{9^{\text {th }}}$ April 1842, British Library, India Office Records, India Secret Proceedings, vol. 80, $29^{\text {th }}$ June 1842 (n. 138).

57. GREY, European Adventurers, op. cit., p. 145. On the aid furnished by the G.G. Lord Ellenborough to Avitabile in retrieving his money, see British Library, India Office Records, F/4/2034/92125, F/ 4/1992/88327.

58. A. BURNES, Cabool: a personal narrative of a Journey to, and residence in that city, in the years 1836-38, London 1843, p. 123.

59. Ibid., p. 124.

60. W. BARR, Journal of a march from Delhi to Peshawar and thence to Kabul, with the mission of Lt. Colonel Sir C.M. Wade, Madden \& Co, London 1844 , p. 286-287.

61. H. HAVELOCK, Narrative of the War in Afghanistan in 1838-1839, vol. II, Henry Colburn, London 1840 , p. 200.

62. D.H. MACKINNON, Military Services and Adventures in the Far East, vol. I, John Ollivier, London 1849, p. 245.

63. H. M. DURAND, Life of Major-Generale Sir Henry Marion Durand, W.H. Allen, London 1883, p. 62-63.

64. On the features of the EIC's expansion, rule, and on his officers' temper, see H.V. BOWEN, The Business of Empire. The East India Company \& Imperial Britain, 1756-1833, Cambridge, Cambridge University Press, 2006; T. W. NECHTMANN, Nabobs. Empire \& Identity in Eighteenth-Century Britain, Cambridge, Cambridge University Press, 2010.

65. BURNES, Cabool, op. cit., p. 125.

66. The Reverend Joseph Wolff met him in Wazirabad and was greatly impressed by his personality, dedicating him a spot in his memories, with numerous praises about his government. The same was by the Austrian Charles von Hugel, who appreciated Avitabile's ability as a ruler. The German Baron Erich von Schomberg, finally, had for the Neapolitan (whom he met in his final year at Lahore) esteem larger than any other, absolving him by the accusations of cruelty and stating that "he ever knew anybody who took more pleasure in doing good than General Avitabelli [sic]".

67. "General Avitabili [sic] has many of the attributes of a good ruler; he is bold, active and intelligent, seeing everything with his own eyes; up early and late". H.M. LAWRENCE, Adventures of an Officer in the Paunjab, Henry Colburn, London 1846, p. 45.

68. Ibid., p. 44.

69. Ibid., p. 43-44.

70. Ibid., p. 45.

71. Ibid., p. 45.

La Révolution française, 8 | 2015 
72. C. MACKENZIE, Storms and Sunshine of a Soldier's Life, vol. I, Douglas, Edinburgh 1884, p. 128-129.

73. Ibid., p. 128-129.

74. Ibid., p. 145.

75. Ibid., p. 147-148.

76. Ibid., p. 147.

77. Ibid., p. 147.

78. Ibid., p. 130.

79. Ibid., p. 157-159.

80. Ibid., p. 130.

81. J.D. CUNNINGHAM, A History of the Sikhs, from the Origin of the Nation to the Battles of the Sutlej, John Murray, London 1849, p. 153-157, 223.

82. J.W. KAYE, History of the War in Afghanistan, Richard Bentley, London 1851, p. 25-31, 392 (vol. II); 16-17, 35-38 (vol. III).

83. H.M. DURAND, The First Afghan War and its causes, Longmans, Greens \& Co., London 1879, p. 218, 387.

84. H. EDWARDES, Life of Sir Henry Lawrence, Smith Elder \& Co, London 1872, p. 292-294.

85. F. P. GiBBon, The Lawrences of the Punjab, J.M. Dent, London 1908, p. 74.

86. In particular Avitabile's supposed insanity caused by alcoholism, cf. James J. cotToN, Il Generale Avitabile, op. cit., p. 105-106. See also J.M. HONIGBERGER, Thirty-Five Years in the East, London 1852, p. 54-55.

87. James J. COTTON, Il Generale Avitabile, op. cit., p. 81-84.

88. GREY, European Adventurers, op. cit., p. 118.

89. Ibid., p. 119.

90. Ibid., p. 119.

91. For the friendly correspondence between the two, vide supra.

92. GREY, European Adventurers, op. cit., p. 147.

93. As an example among many, see C. MILLER, Khyber, British India's North West Frontier. The Story of an Imperial Migraine, MacDonald and Jane's, London 1977, p. 14

94. In fact, Indian post-colonial authors often blame Avitabile also for the aid he offered to the British and for his departure from the Punjab on the eve of the Frist Anglo-Sikh War.

95. O. CAROE, The Pathans 550 B.C.-A.D. 1957. Macmillan and Company, London 1958, p. 315.

96. M. BESSON, Les Aventuriers français aux Indes 1775-1820, Payot, Paris 1932, p. 244-245.

97. P. DOCHERTY, Khyber Pass. A History of Empire and Invasion, Faber, London 2007, p. 199.

98. See note $\mathrm{n}^{\circ} 14$.

99. For the most exaggerated case, see G. IANNETTONE, Presenze italiane lungo le vie dell'Oriente nei secoli XVIII e XIX nella documentazione diplomatico-consolare italiana, Napoli : Edizioni Scientifiche Italiane, 1984, p. 219-240.

100. LAWRENCE, Adventures of an officer, vol. I, op. cit., p. 45.

\section{ABSTRACTS}

After the end of the Napoleonic era, many veterans from the Grande Armée came to India seeking fortune. Among them was the Neapolitan Paolo Avitabile. Formerly an official in the army of Murat, after the Restoration he resigned and departed to Asia. He served as a military 
advisor in Persia (1818-1826) and in the Punjab (1827-1843). There, he was appointed governor of Wazirabad and thence of Peshawar (1837-1843). In the pashtun city, newly acquired and hardly manageable, he ruled on the fierce and lawless tribes of the province with the iron fist, combining local customs and European principles. During the First Afghan War, he dealt with British presence. Among the EIC's officers he earned a swaying reputation: a stern but able governor for some, a bloodthirsty tyrant for others. A reputation they passed on in their memoirs and consequently conveyed by historiography. Avitabile's career is revealing about the connection between adventurers and native states, while the black legend on his rule shows how the British officers and historians saw French-speaking freebooters and their role.

Après la fin de l'ère napoléonienne, de nombreux aventuriers, vétéran de la Grande Armée allaient vers l'Inde en quête de fortune : parmi eux, le napolitain Paolo Avitabile. Ancien officier dans l'armée de Joachim Murat, il partait pour l'Asie suite à la Restauration et était actif en tant que conseiller militaire en Perse (1818-1826) puis au Pendjab (1827-1843), où il fut nommé gouverneur de Wazirabad et plus tard de Peshawar (1837-1843). Dans la ville pashtun, nouvellement acquise et difficilement gouvernable, il gérait avec une main de fer les féroces tribus natives en employant un mélange de coutumes locales et de notions européennes d'autorité politique. Pendant la première guerre anglo-afghane, il faisait face à la présence britannique. Il finit ainsi par avoir une double réputation chez les officiers de la Compagnie britannique des Indes orientales: aux yeux de certains, il était un gouverneur sévère mais habile ; pour d'autres, il était un tyran assoiffé de sang. Les ambigüités de sa notoriété au dixneuvième siècle, évidente dans les journaux de ces officiers, ont été reprises par l'historiographie. La carrière d'Avitabile révèle les connections entre aventuriers et les Etats indiens, et au même temps la 'légende noire' qui entoure son gouvernement montre comme les officiers britanniques, aussi bien que les historiens, voyaient les aventuriers francophones et leur rôle.

\section{INDEX}

Keywords: Paolo Avitabile, Punjab, East India Company, Peshawar, First Afghan War, Grande Armée, European Military Adventurers, Victorian Historiography

Mots-clés: Paolo Avitabile, Pendjab, Compagnie britannique des Indes orientales, Peshawar, Première Guerre Anglo-Afghane, Grande Armée, Aventuriers, militaires, européennes, historiographie victorienne 